\section{Preemergence Herbicides Applied Pre- and Postcrimp in a Rye Cover Crop System for Control of Escape Weeds in Watermelon}

\author{
Lavesta C. Hand ${ }^{1,3,8}$, Wheeler G. Foshee, III $^{1,4}$, Tyler A. Monday ${ }^{1,5}$, \\ Daniel E. Wells ${ }^{1,6}$, and Dennis P. Delaney ${ }^{2,7}$
}

ADDITIONAL INDEX WORDS. cover crop management, fomesafen, ethalfluralin, halosulfuron

Summary. Field studies were conducted in 2016 and 2017 in Tallassee, AL, to evaluate the effect of preemergence (PRE) herbicide applications pre- and postcrimp in a cereal rye (Secale ceveale) cover crop for control of escape weeds in watermelon (Citrullus lanatus). Treatments were arranged in a randomized complete block design with an augmented factorial treatment arrangement with four replications. The augmented factorial arrangement included three levels of PRE herbicides, two levels of application timing, and a nontreated control. PRE herbicide treatments included ethalfluralin ( $18 \mathrm{oz} /$ acre $)$, fomesafen $(2.5 \mathrm{oz} /$ acre $)$, and halosulfuron $(0.56 \mathrm{oz} /$ acre). Application timings were precrimp (herbicide applied before crimping and rolling of the cover crop) and postcrimp (herbicide applied after crimping and rolling of the cover crop). A nontreated cover crop only treatment was also included. There were no interactions among application timing and herbicide. Results indicated application timing influenced total weed coverage but not watermelon yield. Total weed coverage was lowest in precrimp applied treatments at 2,4 , and 6 weeks after treatment (WAT). Comparing individual treatments revealed no significant differences among herbicides with respect to watermelon yield; however, all herbicides increased yield compared with the nontreated.

$\mathrm{W}$ atermelon yield losses due to weed competition in the southeastern United States (Georgia, Florida, Alabama, and South Carolina) are estimated to be $15 \%$ annually (Chandler et al., 1984). Weed control in vegetable crops can be difficult because of the slow growth of the crops and the limited number of registered herbicides (Gilreath and Santos, 2004). Pressure from weed competition increases costs and reduces profit margin because of control costs, difficulty in harvesting, and reduction in crop quality and yield (Brandenberger et al., 2005).

Weed control is especially difficult in watermelon because of their vining growth habit as cultivation is

${ }^{1}$ Department of Horticulture, Auburn University, 101 Funchess Hall, Auburn, AL 36849

${ }^{2}$ Department of Crop, Soil, and Environmental Science, Auburn University, 201 Funchess Hall, Auburn, AL 36849

${ }^{3}$ Graduate Research Assistant.

${ }^{4}$ Associate Professor.

${ }^{5}$ Research Fellow.

${ }^{6}$ Assistant Professor.

${ }^{7}$ Extension Specialist.

${ }^{8}$ Corresponding author. E-mail: 1ch0026@auburn. edu.

https://doi.org/10.21273/HORTTECH03932-17 not feasible after the vines begin to spread into the row middles. The combination of wide row spacing and slow growth of watermelon complicates weed control measures (Terry et al., 1997). Yellow nutsedge (Cyperus esculentus) can reduce watermelon yield by $10 \%$ at 2 plants $/ \mathrm{m}^{2}$ and $66 \%$ at 37 plants $/ \mathrm{m}^{2}$ (Buker et al., 2003). Transplanted watermelons competing with crabgrass (Digitaria sp.) have a critical weed-free period of 0-6 weeks (Monks and Schultheis, 1998). Direct-seeded watermelon competing with smooth pigweed (Amaranthus hybridus) has a critical weed-free period of $0-3$ weeks (Terry et al., 1997). A blend of chemical and cultural controls is often needed to move beyond the critical weed-free period in watermelon (Monday et al., 2015).
Multiple PRE herbicides have been evaluated for use in watermelon and compared based on plant injury and yield (Brandenberger et al., 2005). Halosulfuron applied at any rate injured watermelon; however, in most cases plants recovered by $5-7$ WAT. This also occurred when halosulfuron was tank-mixed with other PRE herbicides. Watermelon yield was greatest and weed control was best with a tank mix of clomazone, ethalfluralin, and halosulfuron. This treatment caused a significant amount of watermelon injury $(30 \%$ at $2-4$ WAT and $26 \%$ at 5-7 WAT), but had no effect on marketable yield (Brandenberger et al., 2005).

Cover crops have been used in numerous cropping systems to improve weed control. In addition to providing weed suppression, benefits of growing a cover crop include improved soil structure, preservation of soil moisture, erosion control, improved water infiltration, and reduced runoff (Teasdale, 1996). Teasdale and Mohler (1993) reported that cover crop residues have an influence on weed populations because of the residue proximity to the site of seed germination. Some weed seeds require light transmittance to germinate, and cover crop residue can reduce the amount of light reaching the soil. Once seeds germinate, they must emerge through a thick layer of mulch likely using much of the seedlings' energy reserves (Teasdale and Mohler, 1993). Therefore, the cover crops can alter the microenvironment around the seed, enough to reduce or delay the weed emergence (Teasdale and Mohler, 1993).

Because of its high biomass production and allelopathic compounds, cereal rye is an excellent cover crop (Barnes and Putnam, 1987; Mwaja et al., 1995). With an average biomass of $6250 \mathrm{~kg} \cdot \mathrm{ha}^{-1}$ at termination, cereal rye alone can reduce palmer amaranth (Amaranthus palmeri) emergence up

\begin{tabular}{llll}
\hline $\begin{array}{l}\text { Units } \\
\begin{array}{l}\text { To convert U.S. to SI, } \\
\text { multiply by }\end{array}\end{array}$ & U.S. unit & SI unit & $\begin{array}{l}\text { To convert SI to U.S., } \\
\text { multiply by }\end{array}$ \\
\hline 0.3048 & $\mathrm{ft}$ & $\mathrm{m}$ & 3.2808 \\
0.0929 & $\mathrm{ft}^{2}$ & $\mathrm{~m}^{2}$ & 10.7639 \\
3.7854 & $\mathrm{gal}$ & $\mathrm{L}$ & 0.2642 \\
9.3540 & gal/acre & $\mathrm{L} \cdot \mathrm{ha}^{-1}$ & 0.1069 \\
2.54 & inch $(\mathrm{es})$ & $\mathrm{cm}$ & 0.3937 \\
1.1209 & lb/acre & $\mathrm{kg} \cdot \mathrm{ha}^{-1}$ & 0.8922 \\
70.0532 & oz/acre & $\mathrm{g} \cdot \mathrm{ha}^{-1}$ & 0.0143
\end{tabular}


to $50 \%$ (Reeves et al., 2005; Webster et al., 2016). In addition, cereal rye produces allelopathic compounds that can inhibit weed growth. Although there are many benefits to growing a cover crop, they only assist in early season weed control (Teasdale, 1996). Herbicides are needed to achieve maximum weed control in a production system using a cover crop.

When cover crops are combined with herbicides, it is possible to achieve satisfactory weed control in vegetables. In a study evaluating squash (Cucurbita pepo), planted behind high biomass varieties of cereal rye, smooth crabgrass (Digitaria ischaemum) and redroot pigweed (Amaranthus retroflexus) were effectively controlled (up to 95\%) when PRE herbicides were used in conjunction with the mulch (Walters et al., 2005). Benefits associated with combining PRE herbicides with mulch were demonstrated in similar studies with fresh market cucumber [Cucumis sativus (Walters et al., 2007)] and pumpkin [C. pepo (Walters et al., 2008)].

Herbicide behavior can be influenced by cover crop residues left on the soil surface (Teasdale et al., 2003). High-residue cover crops can intercept herbicides and reduce efficacy of soil-active herbicides. The herbicide's sorption to the cover crop can render it less active or physically inhibit it from reaching the soil to control emerging weeds (Locke and Bryson, 1997). Teasdale et al. (2003) reported that hairy vetch (Vicia villosa) increased decomposition rates and initial soil solution of metolachlor. This led to reduced grass control and increased pigweed (Amaranthus sp.) emergence (Teasdale et al., 2003). Because of this issue, there is a need to evaluate PRE herbicide application methods to reduce interception and sorption by the cover crop. Cover crop management can also influence weed control. In a study conducted on palmer amaranth control in peanut (Arachis bypogaea), different cover crop management systems were tested in combination with different PRE herbicides (Dobrow et al., 2011). PRE herbicides were applied with no cover crop, with the cover crop rolled, and with the cover crop still standing. The longest period of palmer amaranthfree days occurred when the PRE herbicide was applied with the cover crop left standing.
The objective of this study was to determine if applying PRE herbicides precrimp provides greater nutsedge (Cyperus sp.) and broadleaf weed control than traditional PRE herbicide applications postcrimp in a cereal rye cover crop.

\section{Materials and methods}

Field studies were conducted in 2016 and 2017 at the Auburn University Plant Breeding Unit in Tallassee, AL (lat. $32.43^{\circ} \mathrm{N}$, long. $\left.85.88^{\circ} \mathrm{W}\right)$ to evaluate the effectiveness of applying PRE herbicides preand postcrimp in a cereal rye cover crop for control of broadleaf weeds and nutsedge species in watermelon. Troublesome weed species in this area included sicklepod (Senna obtusifolia), morning glory (Ipomea sp.), palmer amaranth, and nutsedge. The soil type was a Marvyn sandy loam comprising $75.6 \%, 6.8 \%, 17.5 \%$, and $1.0 \%$ sand, silt, clay, and organic matter, respectively, with $\mathrm{pH} 6.2$. Winter cover crops were planted during the second week of September in both years. Cereal rye was planted with a grain drill at a rate of $90 \mathrm{lb} /$ acre and managed according to $\mathrm{Au}$ burn University and Alabama Cooperative Extension System recommended practices (Delaney et al., 2014). The cover crop was ended in the last week of April when rye had reached the soft dough stage in both years. Glyphosate (l lb/acre) was mixed with each treatment to kill the cover crop. After the precrimp treatments were applied, a custom-built cover crop roller (Bigham Brothers, Lubbock, TX) was used to roll and crimp the cereal rye.

Treatments were arranged in a randomized complete block design with an augmented factorial treatment arrangement with four replications. The augmented factorial treatment arrangement included three levels of PRE herbicides, combined with two levels of application timing, and a nontreated control. Application timings were precrimp (herbicide applied before crimp and rolling of the cover crop) and postcrimp (herbicide applied after crimping and rolling of the cover crop). PRE herbicides used were ethalfluralin (18 oz/acre), fomesafen $(2.5 \mathrm{oz} / \mathrm{acre})$, and halosulfuron (0.56 oz/acre). A nontreated cover crop only treatment was included for a total of seven treatments. Herbicide treatments were applied with a 50 -gal sprayer, calibrated to deliver $30 \mathrm{gal} /$ acre with flat-fan nozzles (XR 8004; TeeJet Technologies, Springfield, IL) with a boom width of $15 \mathrm{ft}$ with 20 inch nozzle spacing. Applications were centered over the row. PRE herbicides were applied 1 week before planting.

'Sugar Baby' watermelon was chosen for this study because of its desirable fruit and size. Watermelon was direct seeded and maintained according to commercial production standards (Boyhan et al., 2014). Ammonium sulfate $(30 \mathrm{~N}-0 \mathrm{P}-0 \mathrm{~K}-5 \mathrm{~S})$ and muriate of potash $(0 \mathrm{~N}-0 \mathrm{P}-$ $49.8 \mathrm{~K})$ were applied at $80 \mathrm{lb} /$ acre preplant along with another $80 \mathrm{lb} /$ acre side dressed 6 weeks after planting. Two seeds were planted every $4 \mathrm{ft}$ in parallel rows with five plants per plot. Four 245 - $\mathrm{ft}$ rows were formed as our blocks, each consisting of seven plots, 25 - $\mathrm{ft}$ long with a 6 - $\mathrm{ft}$ buffer between plots. Rows were spaced $25 \mathrm{ft}$ apart to minimize the potential for herbicide drift.

Total weed coverage was visually measured as a percentage within a randomly selected $1-\mathrm{m}^{2}$ section of each plot on a biweekly basis for 8 weeks. Crop yield and fruit number were collected at the end of the season. Data were subjected to analysis of variance in PROC GLIMMIX in SAS (version 9.4; SAS Institute, Cary, $\mathrm{NC}$ ) with the normal distribution and identity link function for yield and negative binomial distribution and $\log$ link function for weed coverage and watermelon count. Total weed coverage, fruit count, and fruit yield were the response variables, and block and year were included in the models as random factors. Differences among individual treatment least squares means were compared and adjusted using the Shaffer-simulated method $(\alpha=0.10)$.

\section{Results}

No interaction occurred by years, so data were pooled across 2016 and 2017. No measurable outcomes were influenced by an interaction of herbicide and application timing; therefore, main effects were analyzed.

Total weed coverage. Total weed coverage was influenced by both herbicide and application timing (Table 1). At 2, 4, and 6 WAT, precrimp-applied treatments $(0.9 \%$, $1.8 \%$, and $3.9 \%$, respectively) reduced weed coverage compared with postcrimp-applied treatments ( $1.8 \%$, 
$2.3 \%$, and $8.8 \%$, respectively) (Table 1 ). Differences in application timing were not observed at 8 WAT. Moreover, halosulfuron $(0.7 \%)$ reduced total weed coverage compared with both ethalfluralin (1.7\%) and fomesafen $(1.7 \%)$ at 2 WAT. Differences in herbicide were not observed across all other rating dates. Halosulfuron had greater weed control at 2 weeks because of its chemical properties. According to the Herbicide Handbook, halosulfuron has a limited residual and breaks down in the soil faster than the other herbicides tested (Senseman, 2007). Comparisons among individual treatments revealed differences only at 6 WAT (Table 1). Weed coverage was reduced in plots treated with ethalfluralin-, fomesafen-, and halosulfuronapplied precrimp $(4.5 \%, 3.1 \%$, and $4.1 \%$, respectively) compared with plots treated with fomesafen-applied postcrimp (15.4\%). Overall, fomesafenapplied precrimp provided the greatest improvement in weed control $(60.7 \%)$ as compared with the nontreated at 6 WAT.

WATERMELON YIELD AND FRUIT count. Watermelon yield and fruit count were not influenced by either herbicide or application timing (Table 2). Comparisons among individual treatments revealed no differences (Table 2). Although no significance was detected, both watermelon yield and fruit count were greater in all precrimp treatments than those of the postcrimp treatments or nontreated. Yield increase was

Table 1. Total weed coverage (palmer amaranth, sicklepod, morning glory, and nutsedge) as influenced by herbicide and application timing in watermelon planted into a rye cover crop in Tallassee, AL. Data for 2016 and 2017 are pooled.

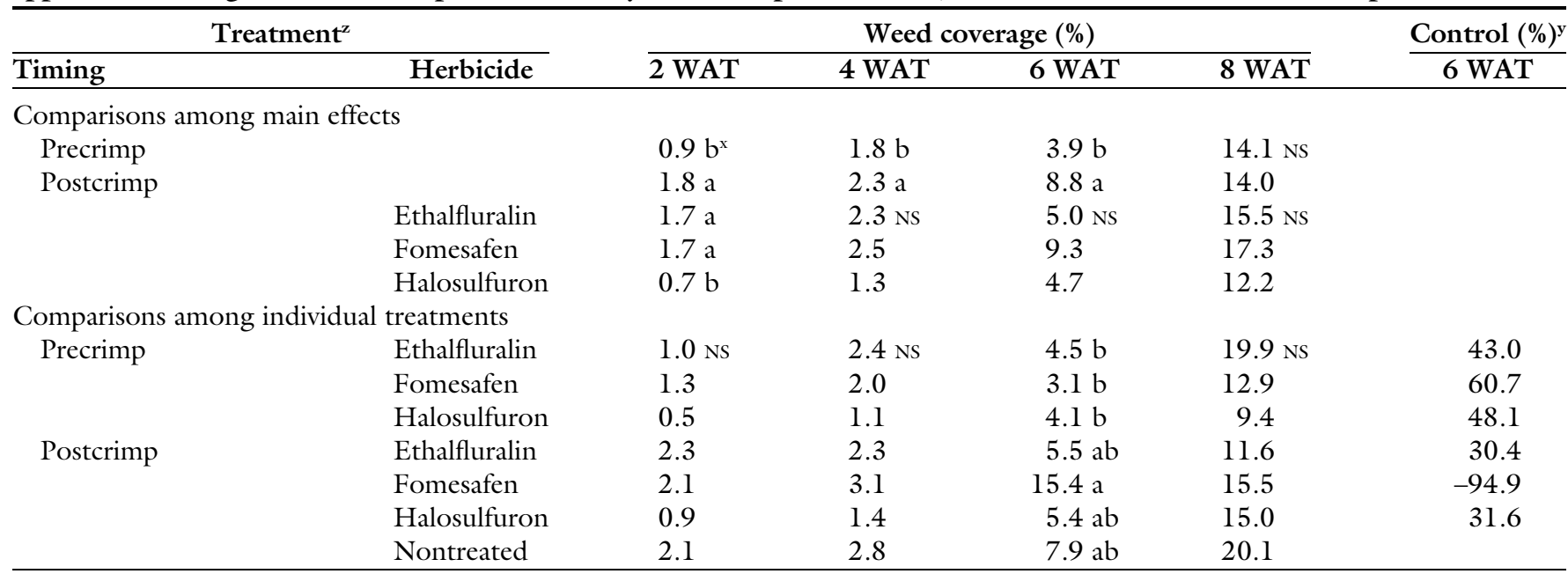

${ }^{\mathrm{z}}$ Timing: precrimp $=$ herbicide treatments were applied either before rolling and crimping the rye cover crop; postcrimp = herbicide treatments were applied after rolling and crimping the rye cover crop. Herbicides were applied at the following rates: ethalfluralin at $18 \mathrm{oz} / \mathrm{acre}$, fomesafen at $2.5 \mathrm{oz} / \mathrm{acre}$, and halosulfuron at $0.56 \mathrm{oz} / \mathrm{acre}(1 \mathrm{oz} / \mathrm{acre}=$ $\left.70.0532 \mathrm{~g} \cdot \mathrm{ha}^{-1}\right)$.

${ }^{\mathrm{y}}$ Percent control as compared with the nontreated. Negative values indicate a decrease in control.

${ }^{\mathrm{x}}$ Means followed by the same letter do not differ according to the Shaffer-simulated test $(\alpha=0.10)$.

NS = nonsignificant; WAT $=$ weeks after treatment.

Table 2. Watermelon yield as influenced by herbicide and application timing in watermelon planted into a rye cover crop in Tallassee, AL. Data for 2016 and 2017 are pooled.

\begin{tabular}{|c|c|c|c|c|}
\hline \multicolumn{2}{|c|}{ Treatment $^{\mathrm{z}}$} & \multicolumn{3}{|c|}{ Watermelon yield ${ }^{y}$} \\
\hline Timing & Herbicide & Fruit (no./ $/ \mathrm{ft}^{2}$ ) & Fruit wt $\left(\mathrm{kg} \cdot \mathrm{ha}^{-1}\right)$ & Yield increase $(\%)^{x}$ \\
\hline \multicolumn{5}{|c|}{ Comparisons among main effects } \\
\hline \multirow[t]{3}{*}{ Postcrimp } & & 0.022 & 9,331 & \\
\hline & Ethalfluralin & $0.027 \mathrm{NS}$ & $10,224 \mathrm{NS}$ & \\
\hline & Fomesafen & 0.026 & 10,191 & \\
\hline \multirow[t]{3}{*}{ Precrimp } & Ethalfluralin & $0.027 \mathrm{NS}$ & $10,471 \mathrm{NS}$ & 16.5 \\
\hline & Fomesafen & 0.029 & 11,632 & 29.4 \\
\hline & Halosulfuron & 0.029 & 11,116 & 23.6 \\
\hline \multirow[t]{2}{*}{ Postcrimp } & Ethalfluralin & 0.026 & 9,976 & 11.0 \\
\hline & Fomesafen & 0.023 & 8,751 & -2.6 \\
\hline
\end{tabular}

${ }^{\mathrm{z}}$ Timing: precrimp $=$ herbicide treatments were applied either before rolling and crimping the rye cover crop; postcrimp $=$ herbicide treatments were applied after rolling and crimping the rye cover crop. Herbicides were applied at the following rates: ethalfluralin at $18 \mathrm{oz} / \mathrm{acre}$, fomesafen at $2.5 \mathrm{oz} / \mathrm{acre}$, and halosulfuron at $0.56 \mathrm{oz} / \mathrm{acre}(\mathrm{loz} / \mathrm{acre}=$ $\left.70.0532 \mathrm{~g} \cdot \mathrm{ha}^{-1}\right)$

${ }^{\mathrm{y}} \mathrm{l}$ fruit $/ \mathrm{ft}^{2}=10.7639$ fruit $/ \mathrm{m}^{2}$ and $\mathrm{l} \mathrm{kg} \cdot \mathrm{ha}^{-1}=0.8922 \mathrm{lb} /$ acre .

${ }^{\mathrm{x}}$ Yield increase as compared with the nontreated. Negative values indicate a decrease in yield.

${ }^{\mathrm{w}}$ Means were compared and did not differ according to the Shaffer-simulated test $(\alpha=0.10)$; Ns $=$ nonsignificant. 
greatest when fomesafen was applied precrimp $(29.4 \%)$ compared with the nontreated.

\section{Discussion}

The primary goal of this research was to determine if applying a PRE herbicide precrimp in a rye cover crop system would improve PRE weed control compared with traditional postcrimp applied herbicides. Data from this study suggest that there is potential for precrimp-applied PRE herbicides to improve weed control in a cover crop system compared with postcrimpapplied PRE herbicides. At the critical weed-free period for watermelon (6 WAT), the precrimp treatments provided greater weed suppression than postcrimp treatments. Both precrimp and postcrimp treatments provided greater weed suppression as compared with the control. Although none of the treatments provided excellent (90\%) control compared with the nontreated at the critical weed-free period for watermelon, there is potential for weed control to be improved using this system. Although there are no statistical differences in yield, numerically, precrimp treatments had higher yield and fruit count than postcrimp treatments. This could provide benefits to watermelon producers by increasing yield and increasing their profits.

These results are similar to that of previous research performed on different cover crop management techniques and PRE herbicide combinations in peanut (Dobrow et al., 2011). In the aforementioned study, palmer amaranth-free days increased when applying flumioxazin with the cover crop still standing. Palmer amaranth-free days were similar to flumioxazin applied after the rolling and crimping the cover crop. Although these two treatments were similar, palmer amaranthfree days were increased by $8 \mathrm{~d}$ when flumioxazin was applied with the cover crop left standing.

Precrimp herbicide application methods should be further evaluated and improved to resolve some of the issues that were observed. When applying the precrimp treatments, the spray pattern was disturbed by the stems of the cereal rye cover crop, resulting in nonuniform spray coverage. A solution to this issue could be raising the boom height above the rye as well as increasing the spray volume. Strip tilling the cover crop before planting may provide a cleaner seedbed, resulting in greater seedling vigor for direct-seeded watermelon. In the strip-tilled area, the PRE herbicide would obtain better soil contact with the possibility of greater weed control because PRE herbicides must have good soil contact to be activated by rainfall or irrigation. Although this research isolated single PRE herbicides for weed control, it is desirable to have multiple modes of action to control a broader spectrum of weeds and to aid in resistance management. Future research should evaluate PRE herbicide tank mixes used in conjunction with a cover crop as well as measuring herbicide concentration in the soil when applied with a cover crop.

\section{Literature cited}

Barnes, J.P. and A.R. Putnam. 1987. Role of benzoxazinones in allelopathy by rye (Secale cereale L.). J. Chem. Ecol. 13:889-906.

Boyhan, G.E., D.M. Granberry, and W.T. Kelly. 2014. Commercial watermelon production. Univ. Georgia Ext. Bul. 996.

Brandenberger, L.P., J.W. Shrefler, C.L. Webber, III., R.E. Talber, M.E. Payton, L.K. Wells, and M. McClelland. 2005. PRE weed control in direct seeded watermelon. Weed Technol. 19:706-712.

Buker, R.S., III, W.M. Stall, S.M. Olson, and D.G. Schilling. 2003. Season long interference of yellow nutsedge (Cyperus esculentus) with direct-seeded and transplanted watermelon (Citrullus lanatus). Weed Technol. 17:751-754.

Chandler, J.M., A.S. Hamel, and A.G. Thomas. 1984. Crop losses due to weeds in Canada and the United States: Special report of the losses due to weeds committee. Weed Sci. Soc. Amer. Mtg., Champaign, IL. p. 1-22.

Delaney, D.P., K.V. Iversen, K.S. Balkcom, and A.W. Caylor. 2014. Cover crops for Alabama. Alabama Coop. Ext. System Publ. ANR-2139.

Dobrow, M.H., Jr., J.A. Ferrell, W.H. Faircloth, G.E. MacDonald, B.J. Brecke, and J.E. Erickson. 2011. Effect of cover crop management and PRE herbicides on the control of ALS-resistant palmer amaranth in peanut. Peanut Sci. 38:73-77.

Gilreath, J.P. and B.M. Santos. 2004. Efficacy of methyl bromide alternatives on purple nutsedge (Cyperus rotundus) control in tomato and pepper. Weed Technol. 18:341-345.

Locke, M.A. and C.T. Bryson. 1997. Herbicide-soil interactions in reduced tillage and plant residue management systems. Weed Sci. 45:307-320.

Monday, T.A., D.A. Lawrence, W.G. Foshee, III, G.R. Wehtje, and C.H. Gilliam. 2015. Pre and post herbicides in combinations with a rye cover crop for control of yellow nutsedge and pigweed in watermelon. Intl. J. Veg. Sci. 21:264-271.

Monks, D.W. and J.R. Schultheis. 1998. Critical weed-free period for large crabgrass (Digitaria sanguinalis) in transplanted watermelon (Citrullus lanatus). Weed Sci. 46:530-532.

Mwaja, V.N., J.B. Masiuna, and L.A. Weston. 1995. Effects of fertility on biomass, phytotoxicity, and allelochemical content of cereal rye. J. Chem. Ecol. 21:81-96.

Reeves, D.W., A.J. Price, and M.G. Patterson. 2005. Evaluation of three winter cereals for weed control in conservation-tillage nontransgenic cotton. Weed Technol. 19:731-736.

Senseman, S.A. (ed.). 2007. Herbicide handbook. 9th ed. Weed Sci. Soc. Amer., Champaign, IL.

Teasdale, J.R. 1996. Contribution of cover crops to weed management in sustainable agriculture systems. J. Prod. Agr. 9:431-479.

Teasdale, J.R. and C.L. Mohler. 1993. Light transmittance, soil temperature, and soil moisture under residue of hairy vetch and rye. Agron. J. 85:673-680.

Teasdale, J.R., D.R. Shelton, A.M. Sadeghi, and A.R. Isensee. 2003. Influence of hairy vetch residue on atrazine and metolachlor soil solution concentration and weed emergence. Weed Sci. 51:628-634.

Terry, E.R., W.M. Stall, D.G. Shilling, T.A. Bewick, and S.R. Kostewicz. 1997. Smooth amaranth interference with watermelon and muskmelon production. HortScience 32:630-632.

Walters, A.S., S.A. Nolte, and B.G. Young. 2005. Influence of winter rye and PRE herbicides on weed control in notillage zucchini squash production. HortTechnology 15:238-243.

Walters, A.S., B.G. Young, and R.F. Krausz. 2008. Influence of tillage, cover crop, and PRE herbicides on weed control and pumpkin yield. Intl. J. Veg. Sci. 14:148-161.

Walters, A.S., B.G. Young, and S.A. Nolte. 2007. Cover crop and PRE herbicide combinations in no-tillage fresh market cucumber production. J. Sustain. Agr. 30(3):5-19.

Webster, T.M., D.B. Simmons, A.S. Culpepper, T.L. Grey, D.C. Bridges, and B.T. Scully. 2016. Factors affecting potential for palmer amaranth (Amaranthus palmeri) suppression by winter rye in Georgia, USA. Field Crops Res. 192:103-109. 